\title{
Longitudinal Analysis to Assess the Contribution of the Multi-Month Scripting (MMS) Regime on ART Outcomes among Adult (15+) Persons Living with HIV in
}

\section{Zimbabwe}

\author{
Hamfrey Sanhokwe ${ }^{1}$, Patrick Shabangu ${ }^{2}$ and Fastel Chipepa ${ }^{1 *}$ \\ ${ }^{1}$ Department of Applied Mathematics and Statistics, Midlands State University, Zimbabwe \\ ${ }^{2}$ Country Director, Institute for Health Measurement, Mbabane, Swaziland
}

*Corresponding author: Fastel Chipepa, Department of Applied Mathematics and Statistics, Midlands State University, Zimbabwe, Tel: +2687 76027521; E-mail: fastel.chipepa@gmail.com

Received: 19 Dec, 2018 | Accepted: 12 Mar, 2019 | Published: 19 Mar, 2019

Citation: Sanhokwe H, Shabangu P, Chipepa F (2019) Longitudinal analysis to Assess the Contribution of the Multi-Month Scripting (MMS) Regime on ART Outcomes among Adult (15+) Persons Living with HIV in Zimbabwe. J HIV AIDS 5(2): dx.doi.org/10.16966/2380-5536.163

Copyright: (c) 2019 Sanhokwe H, et al. This is an open-access article distributed under the terms of the Creative Commons Attribution License, which permits unrestricted use, distribution, and reproduction in any medium, provided the original author and source are credited.

\section{Introduction}

Acquired Immuno Deficiency Syndrome (AIDS) continue to be a major global public health concern. There are an estimated 1.3 million people living with in Zimbabwe and 1,100,000 million were estimated to be on Antiretroviral Therapy (ART) by 2018 [1]. As part of the continued efforts to scale up client focused ART program at a global level, WHO released guidance (the 2013 guidelines, followed by the 2016 guidelines) [2,3] focused on Differentiated Models of Care (DMC). DMC is meant to ensure that HIV services across the cascade reflect the preferences and expectations of various groups of people living with HIV, while enhancing service delivery.

In Zimbabwe, two models of differentiated care for stable patients stand out: the adjusted appointment spacing through Multi-Month Scripting (MMS) and community ART groups (CAGs). MoHCC released an updated Operational and Service Delivery Manual for the Prevention, Care and Treatment of HIV in Zimbabwe (OSDM) in February 2017. This is the second edition of the manual originally developed in 2015. It sets out 'how' to implement WHO's 2016 [3] clinical guidelines, including differentiated service delivery (DMC) across the entire HIV cascade from prevention to suppression. The aim of the study is to assess the contribution of the Multi-Month Scripting (MMS) regime on ART outcomes among adult persons living with HIV in Zimbabwe.

\section{Methodology}

\section{Study design and data sources}

This is a retrospective cohort analysis of treatment outcomes. Data were abstracted from the OI/ART patient care booklets for clients initiated on ART between October 2012 and March 2013. Data was abstracted for a 60-month period. MMS was the exposure variable, while the outcomes of interest are (clinical outcomes (weight gain, OIs, TB AEs); survival status, adherence; and retention. Below is a construct of the key outcome variables for the study (Table 1).

\section{Study population}

Site selection: Data were collected from all five MOHCC facilities in Chitungwiza; namely Chitungwiza Central Hospital, Seke North Clinic, Seke South Clinic, St Mary's Clinic and Zengeza Clinic. Data was abstracted for the period April 2013 to March 2017.

Patient inclusion criteria: All HIV positive clients 15 years and older, who were initiated on ART between the October 2012 and March 2013, at the five ART sites in Chitungwiza, regardless of treatment outcome, were included in the study. This is because clients would be put on MMS only if they have been on ART for at least 6 months and are stable.

Patient exclusion criteria: Patients initiated on ART after March 2013 was excluded from the study. Patients without a documented ART initiation date were excluded from the study.

\section{Sample size}

It is important to note that the study sought to detect the contribution of MMS on ART outcomes (Table 2). The following formula was used to come up with the sample size:

$$
\begin{aligned}
& n=\left[p(100-p) / \Delta^{\wedge} 2 \times \mathrm{f}(1-\propto)\right] \\
& \mathrm{n}=\text { computed sample size } \\
& \mathrm{p}=\text { estimate of the proportion } \\
& \Delta=\text { the desired width of the confidence interval } \\
& 1-\propto=\text { confidence level }
\end{aligned}
$$

Table 1: The key outcome variables.

\begin{tabular}{|l|l|}
\hline \multicolumn{1}{|c|}{ Domain } & \multicolumn{1}{c|}{ Variable } \\
\hline Survival status & Dead or alive \\
\hline Retention & Loss to follow up, on time pill pick up (active client) \\
\hline $\begin{array}{l}\text { Immunological/ } \\
\text { Virological response }\end{array}$ & $\begin{array}{l}\text { Change in CD4 count or viral load, treatment } \\
\text { failure }\end{array}$ \\
\hline Clinical outcomes & Weight gain, Ols \\
\hline
\end{tabular}


Table 2: Sample size per health facility.

\begin{tabular}{|l|c|c|}
\hline $\begin{array}{c}\text { Name of Health } \\
\text { Facility }\end{array}$ & Proportion & $\begin{array}{c}\text { Sample size (Sex Distribution (60\%/40\% } \\
\text { for Females and Males on ART) }\end{array}$ \\
\hline $\begin{array}{l}\text { Chitungwiza } \\
\text { Central Hospital }\end{array}$ & 0.443371 & $137(\mathrm{~F}=82 ; \mathrm{M}=55)$ \\
\hline Seke North Clinic & 0.056729 & $18(\mathrm{~F}=11 ; \mathrm{M}=7)$ \\
\hline Seke South Clinic & 0.196021 & $60(\mathrm{~F}=36 ; \mathrm{M}=24)$ \\
\hline St Mary's Clinic & 0.127106 & $39(\mathrm{~F}=24 ; \mathrm{M}=15)$ \\
\hline Zengeza Clinic & 0.176786 & $56(\mathrm{~F}=33 ; \mathrm{M}=23)$ \\
\hline Total & 1 & $310(\mathrm{~F}=186 ; 124)$ \\
\hline
\end{tabular}

This implied that the study needed to sample a minimum of 310 OI/ART Patient Care Booklets to generate 95\% confidence intervals with $+/-2.5 \%$ bounds around the proportion of interest. The sample is distributed as follows, per site, using probability proportional to size (as per their ART volume in June 2013).

\section{Data collection}

The following process was followed.

- One team of four data abstracters worked on this process.

- When the team arrived at the clinic, the abstractors met with and oriented one to two clinic staff about the objectives of the study and sought for any adult ART patient registers.

- The study numbers on each data extraction form are different to these unique identification numbers. In this way, there were no unique identifiers on any of the data abstraction forms that will allow data, collected on the form, to be linked with a specific patient attending the clinic.

- Where registers were not available, numbers were assigned to all adult ART patient OI/ART Patient Care Booklets for the purpose of sampling.

- Once numbers were assigned to all adult ART patient OI/ART Patient Care Booklets, Microsoft Excel was used to generate a list of randomly ordered ART OI/ART Patient Care Booklets at each site. The first sequential OI/ART Patient Care Booklets in the list were then selected for review until the quota for the site is reached.

- Data was abstracted using a standard data abstraction tool.

- A "study register" was created during chart review to document which records were not found or which were discarded due to one of the different exclusion criteria. The study register will not have any patient name. The study register was used to document the number of missing records at the facility and provide recommendations to the MoHCC at the end of the study.

- Feedback was given to the clinical staff at the end of the session based on the observations of the abstractors. Feedback focused on the importance quality data for patient monitoring.

- The data was captured using tablets running on an ODK platform. After each site visit, all the data would be sync into a database.

\section{Data analysis}

All analyses were performed using STATA 13 software. Data management was performed, checking the data for completeness and consistency. Variables were managed using recode, encode, generate, destring, and tabstat commands in STATA 13 software. Univariate analysis was conducted to come with descriptive statistics and pictorial representations. The Wilcoxon matched-pairs signed-ranks test was applied to test for median difference between baseline CD4 and CD4 follow up, and baseline weight and follow-up weight, respectively.
The Kaplan Meier and Nelson-Aalen methods were used to model survivorship function curves for retention and survival time, stratified by selected independent variables. The log-rank test was performed to test the significance of the difference in retention and survival for selected categorical variables.

\section{Ethical considerations}

Clearance was sought from the MOHCC Head Office, the Chitungwiza Central Hospital CEO, the Superintendent at CITIMED Chitungwiza Hospital and the Chitungwiza City Health Department. To ensure confidentiality, no personally identifiable information relating to clients, such as patient name or clinic registration, number were collected during chart extraction. All the data was kept by the principal investigator on a personal computer with a passwordprotected login screen.

\section{Results}

\section{Demographic characteristics}

Three hundred and five (305) respondents were considered in the study, with 196 being clients on MMS. $60 \%$ of the sample was composed of females. Seventy-six percent $(76 \%)$ of the respondents were in the 25-49-year category. Majority of the females were in the 30-34-year age category. Males had a bimodal distribution in the 35-39 and $40-49$-year age category. Sixty percent $(60 \%)$ of the respondents were females. As shown in table 3 below, there are apparent age-sex specific differences worth mentioning. For instance, the majority of the females included in the study were in the 30-34-year age group, while for men the data shows a seemingly bimodal distribution for 35-39 and 40-44-year age groups. Sixty-four percent (64\%) of the clients were married, $18 \%$ were widowed, $10 \%$ were divorced and $7 \%$ were single. Table 3 shows other demographic characteristics of the respondents.

The majority $(71 \%)$ of the clients attained a secondary level of education. Only one percent of both males and females reached tertiary level. In addition, only one percent did not have any level of education. Fifty-eight percent (58\%) of the respondents were enrolled

Table 3: Marital status and level of education of respondents.

\begin{tabular}{|l|c|c|c|c|c|c|}
\hline $\begin{array}{l}\text { Demographic } \\
\text { Variable }\end{array}$ & \multicolumn{2}{|c|}{$\begin{array}{c}\text { Female ART } \\
\text { Clients }\end{array}$} & \multicolumn{2}{c|}{ Male ART Clients } & \multicolumn{2}{c|}{ Over all Sample } \\
\hline Marital Status & Number & Percent & Number & Percent & Number & Percent \\
\hline Divorced & 24 & $13 \%$ & 5 & $4 \%$ & 29 & $10 \%$ \\
\hline Married & 99 & $54 \%$ & 96 & $79 \%$ & 195 & $64 \%$ \\
\hline Single & 13 & $7 \%$ & 9 & $7 \%$ & 22 & $7 \%$ \\
\hline Widowed & 47 & $26 \%$ & 9 & $7 \%$ & 56 & $18 \%$ \\
\hline $\begin{array}{l}\text { Unknown } \\
\text { Status }\end{array}$ & 0 & $0 \%$ & 3 & $2 \%$ & 3 & $1 \%$ \\
\hline Total & 183 & $100 \%$ & 122 & $100 \%$ & 305 & $100 \%$ \\
\hline & 2 & $1 \%$ & 1 & $1 \%$ & 3 & $1 \%$ \\
\hline None & 27 & $15 \%$ & 10 & $8 \%$ & 37 & $12 \%$ \\
\hline Primary & 123 & $67 \%$ & 95 & $78 \%$ & 218 & $71 \%$ \\
\hline Secondary & 2 & $1 \%$ & 1 & $1 \%$ & 3 & $1 \%$ \\
\hline Tertiary & 9 & $16 \%$ & 15 & $12 \%$ & 44 & $14 \%$ \\
\hline $\begin{array}{l}\text { Unknown } \\
\text { Level }\end{array}$ & 183 & $100 \%$ & 122 & $10 \%$ & 305 & $100 \%$ \\
\hline Total & & \multicolumn{7}{|c|}{ Level of Education } & & \\
\hline
\end{tabular}

Source: Study data, 2017 
through VCT. Thirty-seven percent (37\%) of the sampled clients were in WHO clinical stage III, see table 3 for more detail.

Of the total sample, $23 \%$ did not have a CD4 count done $(42 / 183$ women and 29/122 men) as shown in table 4 above. In 2012/13, where point of care $\mathrm{CD} 4$ counts was done, ART initiations were restricted to those with a CD4 cell count of 350 cells $/ \mu \mathrm{L}$ or less. The exceptions to this rule were pregnant women as well as those who were TB-HIV co-infected regardless of sex. The proportion of those with/without a documented CD4 result was the same for both males and females. The average CD4 count at initiation was 334 cells $/ \mu \mathrm{L}$ for females and 289 cells $/ \mu \mathrm{L}$ for males.

\section{Treatment outcomes analysis}

Survival time: As shown in table 5, the incidence rate (failure rate) was, on average, 19 per 1000 across the age groups. It was highest, at 20 per 1000, among the 40-44 year olds and lowest among the 25-29-year age group. The median survival time is 53 months (out of a possible $60)$ as shown below. The median survival time is lowest in the 15-19 year age group and highest in the 20-24 and 50+ year age groups. The incidence rate and survival time are not different for both gender and MMS status (Table 6).

As shown in table 4 below, there were two failures (deaths) in the first six months after ART initiation (rate of 1.1038, 95\% CI: 0.28-4.41). In addition, there were 2 failures in the 42-48-month period (rate of 1.1869436; 95\% CI: 0.2968518-4.745921). There was also one death in the 54-60-month period (rate of 5.4317824; 95\% CI: .0.765562438.58191).

A further interrogation of the data shows that four of the five failures occurred among clients with no TB as shown in table 7. However, as shown in the same table, the survivor function (probability of surviving beyond time, $t$,) was higher among clients without TB compared to those diagnosed with TB.

Retention: For retention, the incidence rate (attrition rate) was, on average, 18 per 1000 as shown in table 8 . It was highest among the 40-44-year age group (18.2 per 1000) and lowest among the 2529 -year age group (16.5 per 1000). The median retention time was 53 months. Median retention time was lowest in the 15-19-year age group compared to the other age groups. As with survival, the median retention time was the same between males and females, at 53 months, and so were the incidence rates (17 per 1000). Similarly, the data shows no differences in the median retention time between ART clients diagnosed with TB and those with no TB regardless of MMS status.

Table 4: Survival over time.

\begin{tabular}{|l|c|c|c|c|c|}
\hline \multicolumn{1}{|c|}{ Cohort } & Person-time & Failure & Rate & \multicolumn{2}{c|}{$\begin{array}{c}\text { 95\% Confidence } \\
\text { Interval }\end{array}$} \\
\hline 0-6 months & 1812 & 2 & 1.104 & 0.276 & 4.413 \\
\hline 6-12 months & 1788 & 0 & - & - & - \\
\hline 12-18 months & 1782 & 0 & - & - & - \\
\hline 18-24 months & 1772 & 0 & - & - & - \\
\hline 24-30 months & 1766 & 0 & - & - & - \\
\hline 30-36 months & 1760 & 0 & - & - & - \\
\hline 36-42 months & 1744 & 0 & - & - & - \\
\hline $42-48$ months & 1685 & 2 & 1.187 & 0.297 & 4.746 \\
\hline $48-54$ months & 254 & 0 & 0 & - & - \\
\hline 54-60 months & 184 & 1 & 5.434 & 0.766 & 38.582 \\
\hline Total & 15561 & 5 & 0.321 & - & - \\
\hline
\end{tabular}

Source: Study data, 2017.
Table 5: Clinical characteristics of the sampled male and female clients.

\begin{tabular}{|c|c|c|c|c|c|c|}
\hline \multirow{2}{*}{\begin{tabular}{|l|}
$\begin{array}{c}\text { Referral source } \\
\text { for HIV care }\end{array}$ \\
and Treatment \\
VCT
\end{tabular}} & \multicolumn{2}{|c|}{$\begin{array}{l}\text { Female ART } \\
\text { Clients }\end{array}$} & \multicolumn{2}{|c|}{ Male ART Clients } & \multicolumn{2}{|c|}{ Overall Sample } \\
\hline & 89 & $49 \%$ & 87 & $71 \%$ & 176 & $58 \%$ \\
\hline TB Clinics & 5 & $3 \%$ & 10 & $8 \%$ & 15 & $5 \%$ \\
\hline PMTCT & 13 & $7 \%$ & 0 & $0 \%$ & 13 & $4 \%$ \\
\hline Obstetrics Unit & 10 & $5 \%$ & 0 & $0 \%$ & 10 & $3 \%$ \\
\hline Hospitalization & 62 & $34 \%$ & 23 & $19 \%$ & 85 & $28 \%$ \\
\hline Home & 1 & $1 \%$ & 0 & $0 \%$ & 1 & $0 \%$ \\
\hline Other & 3 & $2 \%$ & 2 & $2 \%$ & 5 & $2 \%$ \\
\hline Total & 183 & $100 \%$ & 122 & $100 \%$ & 305 & $100 \%$ \\
\hline $\begin{array}{l}\text { WHO Stage at } \\
\text { Initiation }\end{array}$ & Number & Percent & Number & Percent & Number & Percent \\
\hline Stage I & 55 & $30 \%$ & 20 & $16 \%$ & 75 & $25 \%$ \\
\hline Stage II & 73 & $40 \%$ & 40 & $33 \%$ & 113 & $37 \%$ \\
\hline Stage III & 49 & $27 \%$ & 59 & $48 \%$ & 108 & $35 \%$ \\
\hline Stage IV & 6 & $3 \%$ & 3 & $2 \%$ & 9 & $3 \%$ \\
\hline Total & 183 & $100 \%$ & 122 & $100 \%$ & 305 & $100 \%$ \\
\hline \multicolumn{7}{|c|}{ CD4+ Cell Count Done } \\
\hline Yes & 42 & $23 \%$ & 29 & $24 \%$ & 71 & $23 \%$ \\
\hline No & 141 & $77 \%$ & 93 & $76 \%$ & 234 & $77 \%$ \\
\hline Total & 183 & $100 \%$ & 122 & $100 \%$ & 305 & $100 \%$ \\
\hline \multicolumn{7}{|c|}{ Pre-ART Exposure } \\
\hline HAART & 39 & $21 \%$ & 21 & $17 \%$ & 60 & $20 \%$ \\
\hline РМТCT & 7 & $4 \%$ & 0 & $0 \%$ & 7 & $2 \%$ \\
\hline SD NVP & 4 & $2 \%$ & 1 & $1 \%$ & 5 & $2 \%$ \\
\hline None & 133 & $73 \%$ & 100 & $82 \%$ & 233 & $76 \%$ \\
\hline Total & 183 & $100 \%$ & 122 & $100 \%$ & 305 & $100 \%$ \\
\hline \multicolumn{7}{|c|}{ Exposure to OI prior to ART initiation } \\
\hline TB & 9 & $5 \%$ & 21 & $17 \%$ & 30 & $10 \%$ \\
\hline Other OI & 36 & $20 \%$ & 16 & $13 \%$ & 52 & $17 \%$ \\
\hline None & 138 & $75 \%$ & 85 & $70 \%$ & 223 & $73 \%$ \\
\hline Total & 183 & $100 \%$ & 122 & $100 \%$ & 305 & $100 \%$ \\
\hline
\end{tabular}

Source: Study data, 2017.

Table 6: Survival time data by age, sex and MMS status.

\begin{tabular}{|l|c|c|c|c|c|c|}
\hline \multicolumn{1}{|c|}{ Variable } & $\begin{array}{c}\text { Time at } \\
\text { risk }\end{array}$ & $\begin{array}{c}\text { Incidence } \\
\text { rate }\end{array}$ & $\begin{array}{c}\text { Number of } \\
\text { subjects }\end{array}$ & \multicolumn{3}{|c|}{ Survival Time } \\
\hline Age Group & & & & $25 \%$ & $50 \%$ & $75 \%$ \\
\hline 15-19 years & 311 & 0.0192 & 6 & 51 & 51 & 53 \\
\hline 20-24 years & 375 & 0.0187 & 52 & 53 & 54 & 55 \\
\hline 25-29 years & 1699 & 0.0182 & 32 & 52 & 53 & 56 \\
\hline 30-34 years & 2686 & 0.019 & 51 & 52 & 53 & 55 \\
\hline $35-39$ years & 2952 & 0.019 & 56 & 51 & 53 & 55 \\
\hline 40-44 years & 2028 & 0.0197 & 42 & 52 & 52 & 55 \\
\hline $45-49$ years & 782 & 0.0191 & 15 & 51 & 52 & 55 \\
\hline $50+$ years & 1383 & 0.0188 & 28 & 52 & 54 & 55 \\
\hline Total & $\mathbf{1 2 2 1 6}$ & $\mathbf{0 . 0 1 9}$ & $\mathbf{2 3 7}$ & $\mathbf{5 2}$ & $\mathbf{5 3}$ & $\mathbf{5 5}$ \\
\hline Sex & & & & & & \\
\hline Male & 6121 & 0.0191 & 121 & 51 & 53 & 55 \\
\hline Female & 9440 & 0.0193 & 183 & 51 & 53 & 55 \\
\hline Total & 15561 & 0.0192 & 304 & 51 & 53 & 55 \\
\hline MMS & & & & & & \\
\hline No & 5541 & 0.0195 & 108 & 51 & 53 & 55 \\
\hline Yes & 10020 & 0.0191 & 196 & 51 & 53 & 55 \\
\hline Total & $\mathbf{1 5 5 6 1}$ & $\mathbf{0 . 0 1 9 2}$ & $\mathbf{3 0 4}$ & $\mathbf{5 1}$ & $\mathbf{5 3}$ & $\mathbf{5 5}$ \\
\hline & & & & & & \\
\hline
\end{tabular}

Source: Study data, 2017. 
Table 7: The survival function stratified by TB status.

\begin{tabular}{|l|c|c|c|c|c|c|}
\hline No TB & $\begin{array}{c}\text { Beginning } \\
\text { Total }\end{array}$ & Fail & $\begin{array}{c}\text { Survivor } \\
\text { Function }\end{array}$ & $\begin{array}{c}\text { Standard } \\
\text { Error }\end{array}$ & $\begin{array}{c}95 \% \text { Confidence } \\
\text { Interval }\end{array}$ \\
\hline 6 months & 271 & 1 & 0.9964 & 0.0036 & 0.9744 & 0.9995 \\
\hline 12 months & 271 & 0 & 0.9964 & 0.0036 & 0.9744 & 0.9995 \\
\hline 24 months & 269 & 0 & 0.9964 & 0.0036 & 0.9744 & 0.9995 \\
\hline 36 months & 267 & 0 & 0.9964 & 0.0036 & 0.9744 & 0.9995 \\
\hline 48 months & 247 & 2 & 0.9887 & 0.0065 & 0.9654 & 0.9963 \\
\hline 60 months & 4 & 1 & 0.9768 & 0.0135 & 0.9285 & 0.9926 \\
\hline Diagnosed with TB \\
\hline 6 months & 29 & 1 & 0.9667 & 0.0328 & 0.7861 & 0.9952 \\
\hline 12 months & 29 & 0 & 0.9667 & 0.0328 & 0.7861 & 0.9952 \\
\hline 24 months & 28 & 0 & 0.9667 & 0.0328 & 0.7861 & 0.9952 \\
\hline 36 months & 28 & 0 & 0.9667 & 0.0328 & 0.7861 & 0.9952 \\
\hline 48 months & 27 & 0 & 0.9667 & 0.0328 & 0.7861 & 0.9952 \\
\hline 60 months & 1 & 0 & & & & \\
\hline
\end{tabular}

Source: Study data, 2017.

Table 8: Retention over time, by age, sex, MMS status and TB status.

\begin{tabular}{|c|c|c|c|c|c|c|}
\hline \multirow{2}{*}{$\begin{array}{r}\text { Variable } \\
\text { Age Group }\end{array}$} & \multirow[t]{2}{*}{$\begin{array}{c}\text { Time at } \\
\text { risk }\end{array}$} & \multirow{2}{*}{$\begin{array}{c}\text { Incidence } \\
\text { rate }\end{array}$} & \multirow{2}{*}{$\begin{array}{c}\text { Number of } \\
\text { subjects }\end{array}$} & \multicolumn{3}{|c|}{ Survival Time } \\
\hline & & & & $25 \%$ & $50 \%$ & $75 \%$ \\
\hline $15-19$ years & 311 & 0.0161 & 6 & 51 & 51 & 53 \\
\hline $20-24$ years & 375 & 0.0187 & 52 & 52 & 53 & 54 \\
\hline $25-29$ years & 1699 & 0.0165 & 32 & 52 & 53 & 56 \\
\hline 30-34 years & 2686 & 0.0179 & 51 & 52 & 53 & 55 \\
\hline $35-39$ years & 2952 & 0.0176 & 56 & 52 & 54 & 55 \\
\hline $40-44$ years & 2028 & 0.01182 & 42 & 52 & 53 & 55 \\
\hline $45-49$ years & 782 & 0.0179 & 15 & 52 & 52 & 55 \\
\hline $50+$ years & 1383 & 0.0174 & 28 & 51 & 54 & 55 \\
\hline Total & 12216 & 0.0176 & 237 & 52 & 53 & 5 \\
\hline \multicolumn{7}{|c|}{ Sex } \\
\hline Male & 6121 & 0.0168 & 121 & 52 & 53 & 55 \\
\hline Female & 9440 & 0.0175 & 183 & 52 & 53 & 55 \\
\hline Total & 15561 & 0.0172 & 304 & 52 & 53 & 55 \\
\hline \multicolumn{7}{|c|}{ MMS } \\
\hline No & 5541 & 0.0175 & 108 & 51 & 54 & 55 \\
\hline Yes & 10020 & 0.0171 & 196 & 52 & 53 & 55 \\
\hline & 15561 & 0.0172 & 304 & 52 & 53 & 55 \\
\hline \multicolumn{7}{|c|}{ TB } \\
\hline No TB & 14110 & 0.0172 & 274 & 52 & 53 & 55 \\
\hline $\begin{array}{l}\text { Diagnosed } \\
\text { with TB }\end{array}$ & 1451 & 0.0172 & 30 & 52 & 53 & 55 \\
\hline Total & 15561 & 0.0172 & 304 & 52 & 53 & 55 \\
\hline
\end{tabular}

Source: Study data, 2017.

Table 9 shows retention rates at $6,12,24,36,48$, and at 60 months, by MMS status. Retention was $100 \%$ among clients who were not on MMS. For clients on MMS, retention at 12 and 24 months was $99 \%$, dropping to $98 \%$ at 48 months. The retention rate drops further to $96 \%$ at 60 months. This could partially be explained by reporting issues i.e. how accurately the information system captures MMS.

Immunological response: Table 10 below shows the immunological response changes by sex, MMS status (i.e. on MMS or not on MMS). As shown in the table, there were statistically significant gains in CD4 among all clients, regardless of sex or MMS status $(p=0.00)$, albeit the variation in the mean differences. However, the change in CD4 as measured by the mean difference, was higher (64.63 vs. 32.37) among clients who were not on MMS than those on MMS. This is not surprising given that typically MMS clients are recruited with a minimum CD4 threshold. When further stratified by TB status for both MMS and non-MMS clients, there were statistically significant gains in CD4 cell count across all the strata.

Clinical response: Overall, the median weight gains at 12, 24, 36, 48 and 60 months were $4.2,5.1,5.4,5.9$ and $6.1 \mathrm{kgs}$ respectively among MMS clients as shown in figure 1 below. For non-MMS clients, the median weight gains at 12, 24, 36, 48 and 60 months were 4.1, 5, 5.34, 5.8 and $6.1 \mathrm{kgs}$ respectively. The results were not statistically different between MMS and non-MMS clients ( $\mathrm{p}>0.05)$.

\section{Discussion and Conclusion}

Among the 305 ART clients with HIV/AIDS who initiated ART, there were five failures; two within the first 6 months, two between the 42-48-month period and one in the 54-60-month period. Overall, the median survival time (53 months) was the same among MMS and non-MMS clients. The retention rates at 12, 24, 36, 48 and 60 months were $100 \%$ for non-MMS clients. For MMS clients, retention rates were $99 \%$ at 12 and 24 months, dropping to $98 \%$ at 48 months and to $96 \%$ at 60 months. The results are higher in comparison to a retrospective study by Tsitsi Mutasa-Apollo et al (2014) [4], which showed retention at $6,12,24$ and 36 months as $90.7 \%, 78.1 \%, 68.8 \%$ and $64.4 \%$, respectively. The differences could partially be explained by differences in the time when the two studies were undertaken. In addition, the country's ART program has witnessed significant investments meant to enhance clinical outcomes for ART patients e.g. investments in nurse mentors at facility level, capacity development of health care workers, motivation grants (salary top ups through Global Fund), deployment of community cadres (peer navigators and health care workers) and patient follow-up resources (through both PEPFAR, Global Fund and World Bank) which all help facilitate an effective ART program.

Overall, the median weight gains at 12, 24, 36, 48 and 60 months were $4.2,5.1,5.4,5.8$ and $6.2 \mathrm{kgs}$ respectively. The results were not statistically different between MMS and non-MMS clients. The results are similar to the study by Tsitsi Mutasa-Apollo et al (2014) [4] (for adults $\geq 15$ years initiated on ART from 2007 to 2009) where the median weight gains at 6,12 , and 24 months were $3,4.5$, and $5.0 \mathrm{kgs}$. There was a statistically significant change in the CD4 counts over time for both MMS and non MMS clients. The results also showed that there was no statistically significant change in mean CD4 count among the 15-19 year olds, regardless of MMS status. As highlighted earlier, this is typical of adolescent clients, hence the reason they have CD4 counts done every six-month, yet for adults, once a client is deemed stable, the CD4 or viral load is to be done once a year. The study results do not point to a statistically significant contribution of MMS to observed clinical outcomes. However, the contribution of MMS to observed ART outcomes could as well be clinically significant (Table 11).

\section{Recommendations}

The study findings suggest the need for more research to conclusively determine the contribution of each of the models of differentiated care. There is evidence on the economic benefits of MMS. The fact that it saves on time and space at health facilities is also well documented. The researcher advocates for the following:

- An expanded research, covering a wide spectrum of sites, especially the rural sites, to help understand more the actual net effect of MMS, beyond the documented financial and other resource benefits of MMS at health facility level.

- Conduct an evaluation of the various models of differentiated care individually, and in tandem with others, to assess the net effect of these differentiated models of care, controlling for other factors (e.g. other interventions already in place to enhance patient level ART outcomes). 
Table 9: Retention rates over time.

\begin{tabular}{|c|c|c|c|c|c|c|c|}
\hline MMS & Cohort period & Total & \multicolumn{2}{|c|}{$\begin{array}{c}\text { Attrition } \\
\text { Retention rate }\end{array}$} & SE & $95 \%$ Cl \\
\hline 6 & 6 & 8748 & 0 & 1 &. &. \\
\hline 12 & 12 & 8748 & 0 & 1 &. &. \\
\hline 24 & 24 & 8586 & 0 & 1 &. &. \\
\hline 36 & 36 & 8505 & 0 & 1 &. &. \\
\hline 48 & 48 & 7776 & 0 & 1 &. &. \\
\hline 60 & 60 & 243 & 0 & 1 &. &. \\
\hline \multicolumn{7}{|c|}{ Yes } \\
\hline 6 & 6 & 15552 & 162 & 0.9898 & 0.0008 & $\begin{array}{l}0.9881 \\
0.9912\end{array}$ \\
\hline 12 & 12 & 15552 & 0 & 0.9898 & 0.0008 & $\begin{array}{l}0.9881 \\
0.9912\end{array}$ \\
\hline 24 & 24 & 15471 & 0 & 0.9898 & 0.0008 & $\begin{array}{l}0.9881 \\
0.9912\end{array}$ \\
\hline 36 & 36 & 15390 & 0 & 0.9898 & 0.0008 & $\begin{array}{l}0.9881 \\
0.9912\end{array}$ \\
\hline 48 & 48 & 14337 & 162 & 0.9792 & 0.0011 & $\begin{array}{l}0.9768 \\
0.9813\end{array}$ \\
\hline 60 & 60 & 243 & 81 & 0.9604 & 0.0024 & $\begin{array}{l}0.9555 \\
0.9647\end{array}$ \\
\hline
\end{tabular}

Source: Study data, 2017.

Table 10: Comparison on the changes in CD4 count at initiation with the final follow up CD4 count.

\begin{tabular}{|c|c|c|c|c|c|c|}
\hline Variables & Mean & SE & SD & \multicolumn{2}{|c|}{$95 \% \mathrm{C}$} & P-value \\
\hline \multicolumn{7}{|c|}{ All clients } \\
\hline $\begin{array}{l}\text { Follow-up CD4 } \\
\text { (Cells/mm³ })\end{array}$ & 247.68 & 1.37 & 192.79 & 245 & 250.37 & \\
\hline $\begin{array}{l}\text { Baseline CD4 } \\
\left(\text { Cells } / \mathrm{mm}^{3}\right)\end{array}$ & 204.08 & 0.99 & 138.84 & 202.14 & 206.01 & \\
\hline $\begin{array}{l}\text { Mean difference } \\
\left(\text { Cells } / \mathrm{mm}^{3}\right)\end{array}$ & 43.61 & 1.14 & 160.31 & 41.37 & 45.84 & 0 \\
\hline \multicolumn{7}{|l|}{ Male } \\
\hline $\begin{array}{l}\text { Follow-up CD4 } \\
\text { (Cells/mm³) }\end{array}$ & 202.43 & 2.19 & 190.87 & 198.14 & 206.72 & \\
\hline $\begin{array}{l}\text { Baseline CD4 } \\
\left(\text { Cells } / \mathrm{mm}^{3}\right)\end{array}$ & 163.56 & 1.28 & 111.58 & 161.05 & 166.06 & \\
\hline $\begin{array}{l}\text { Mean difference } \\
\left(\text { Cells } / \mathrm{mm}^{3}\right)\end{array}$ & 38.87 & 1.78 & 155.44 & 35.38 & 42.36 & 0 \\
\hline \multicolumn{7}{|l|}{ Female } \\
\hline $\begin{array}{l}\text { Follow-up CD4 } \\
\text { (Cells/mm³) }\end{array}$ & 276.04 & 1.71 & 188.52 & 272.69 & 279.4 & \\
\hline $\begin{array}{l}\text { Baseline CD4 } \\
\left(\text { Cells } / \mathrm{mm}^{3}\right)\end{array}$ & 229.47 & 1.34 & 147.93 & 226.84 & 232.1 & \\
\hline $\begin{array}{l}\text { Mean difference } \\
\left(\text { Cells } / \mathrm{mm}^{3}\right)\end{array}$ & 46.58 & 1.48 & 163.22 & 43.67 & 49.48 & 0 \\
\hline \multicolumn{7}{|l|}{ MMS-No } \\
\hline $\begin{array}{l}\text { Follow-up CD4 } \\
\text { (Cells/mm³) }\end{array}$ & 243.49 & 2.48 & 205.53 & 238.63 & 248.34 & \\
\hline $\begin{array}{l}\text { Baseline CD4 } \\
\left(\text { Cells } / \mathrm{mm}^{3}\right)\end{array}$ & 178.86 & 1.49 & 123.59 & 175.94 & 181.78 & \\
\hline $\begin{array}{l}\text { Mean difference } \\
\left(\text { Cells } / \mathrm{mm}^{3}\right)\end{array}$ & 64.63 & 2.17 & 179.68 & 60.38 & 68.87 & 0 \\
\hline \multicolumn{7}{|l|}{ MMS-Yes } \\
\hline $\begin{array}{l}\text { Follow-up CD4 } \\
\text { (Cells/mm³) }\end{array}$ & 249.93 & 1.64 & 185.58 & 246.72 & 253.13 & \\
\hline $\begin{array}{l}\text { Baseline CD4 } \\
\left(\text { Cells } / \mathrm{mm}^{3}\right)\end{array}$ & 217.56 & 1.27 & 144.56 & 215.06 & 220.05 & \\
\hline $\begin{array}{l}\text { Mean difference } \\
\left(\text { Cells } / \mathrm{mm}^{3}\right)\end{array}$ & 32.37 & 1.3 & 147.7 & 29.82 & 34.92 & 0 \\
\hline
\end{tabular}

Source: Study data, 2017.
Table 11: Comparing the changes in CD4 count at initiation with the final follow up CD4 count for ART clients with and without TB.

\begin{tabular}{|c|c|c|c|c|c|c|}
\hline Variables & Mean & SE & SD & $95 \%$ & $\mathrm{Cl}$ & P-value \\
\hline \multicolumn{7}{|c|}{ MMS $=$ No \& TB=0 } \\
\hline $\begin{array}{l}\text { Follow-up CD4 } \\
\text { (Cells/mm³) }\end{array}$ & 255.056 & 2.673 & 209.716 & 249.816 & 260.296 & \\
\hline $\begin{array}{l}\text { Baseline CD4 } \\
\left(\text { Cells } / \mathrm{mm}^{3}\right)\end{array}$ & 186.724 & 1.601 & 125.641 & 183.585 & 189.863 & \\
\hline $\begin{array}{l}\text { Mean difference } \\
\left(\text { Cells } / \mathrm{mm}^{3}\right)\end{array}$ & 68.332 & 2.382 & 186.885 & 63.6627 & 73.0014 & 0 \\
\hline \multicolumn{7}{|l|}{ MMS $=$ Yes \& TB=0 } \\
\hline $\begin{array}{l}\text { Follow-up CD4 } \\
\left.\text { (Cells/mm } \mathrm{mm}^{3}\right)\end{array}$ & 259.588 & 1.719 & 187.616 & 256.218 & 262.958 & \\
\hline $\begin{array}{l}\text { Baseline CD4 } \\
\left(\text { Cells } / \mathrm{mm}^{3}\right)\end{array}$ & 225.567 & 1.328 & 144.958 & 222.963 & 228.171 & \\
\hline $\begin{array}{l}\text { Mean difference } \\
\left(\text { Cells } / \mathrm{mm}^{3}\right)\end{array}$ & 34.0204 & 1.403 & 153.064 & 31.2708 & 36.77 & 0 \\
\hline \multicolumn{7}{|l|}{ MMS=No \& TB=1 } \\
\hline $\begin{array}{l}\text { Follow-up CD4 } \\
\text { (Cells/mm³) }\end{array}$ & 145.778 & 4.816 & 130.024 & 136.324 & 155.232 & \\
\hline $\begin{array}{l}\text { Baseline CD4 } \\
\left(\text { Cells } / \mathrm{mm}^{3}\right)\end{array}$ & 112.444 & 2.877 & 77.6665 & 106.797 & 118.092 & \\
\hline $\begin{array}{l}\text { Mean difference } \\
\left(\text { Cells } / \mathrm{mm}^{3}\right)\end{array}$ & 33.3333 & 3.494 & 94.3456 & 26.4733 & 40.1934 & 0 \\
\hline \multicolumn{7}{|l|}{ MMS $=$ Yes \& TB=1 } \\
\hline $\begin{array}{l}\text { Follow-up CD4 } \\
\text { (Cells/mm } \mathrm{mm}^{3} \text { ) }\end{array}$ & 131.583 & 3.211 & 100.093 & 125.283 & 137.884 & \\
\hline $\begin{array}{l}\text { Baseline CD4 } \\
\left(\text { Cells } / \mathrm{mm}^{3}\right)\end{array}$ & 119.417 & 3.057 & 95.293 & 113.419 & 125.415 & \\
\hline $\begin{array}{l}\text { Mean difference } \\
\left(\text { Cells } / \mathrm{mm}^{3}\right)\end{array}$ & 12.1667 & 1.295 & 40.373 & 9.62541 & 14.7079 & 0 \\
\hline
\end{tabular}

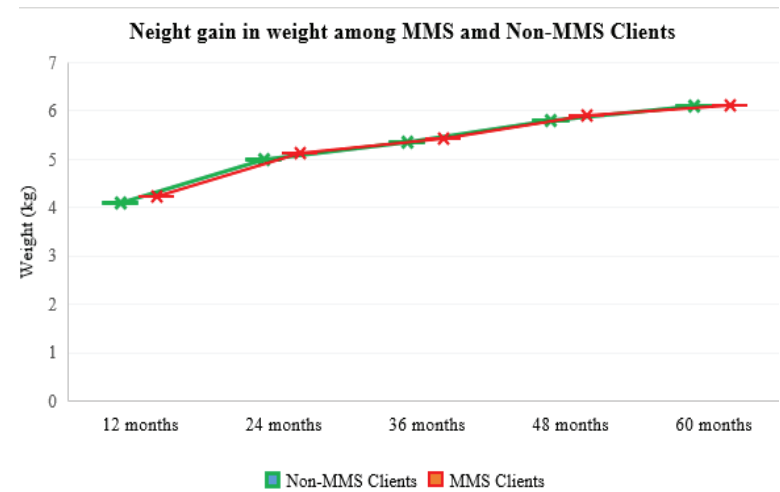

Figure 1: Changes in weight gains at 12, 24, 36, 48 and 60 months for MMS and Non-MMS clients

\section{References}

1. UNAIDS (2018) Global Aids Response Progress Report 2018. National AIDS Council, Ministry of Health and Child care, Zimbabwe.

2. World Health Organization (WHO) (2015) Global health sector response to HIV, 2000-2015: Focus on innovations in Africa: progress report. Geneva, Switzerland.

3. World Health Organization (WHO) (2016) Consolidated guidelines on the use of antiretroviral drugs for treating and preventing HIV infection: Recommendations for a public health approach. $2^{\text {nd }}$ Edition, Geneva, Switzerland.

4. Mutasa-Apollo T, Shiraishi RW, Takarinda KC, Dzangare J, Mugurungi O, et al. (2014) Patient retention, clinical outcomes and attrition-associated factors of HIV-infected patients enrolled in Zimbabwe's national antiretroviral therapy programme, 2007-2010. PLoS One 9: e86305. 